\title{
Guidelines
}

\section{Portuguese Society of Gastroenterology Consensus on the Diagnosis and Management of Hemorrhoidal Disease}

\author{
Paulo Salgueiro ${ }^{a, b}$ Ana Célia Caetano ${ }^{c, d}$ Ana Maria Oliveira ${ }^{e}$ Bruno Rosa $^{f}$ \\ Miguel Mascarenhas-Saraiva ${ }^{g}$ Paula Ministro ${ }^{\text {h }}$ Pedro Amaro $^{\mathrm{i}}$ \\ Rogério Godinhoj Rosa Coelhok ${ }^{k}$ Rúben Gaio $^{b}$ Samuel Fernandes ${ }^{\prime}$ \\ Vítor Fernandes $^{m}$ Fernando Castro-Poças ${ }^{a, b}$
}

a Serviço Gastroenterologia, Centro Hospitalar e Universitário do Porto, Porto, Portugal; 'b Instituto de Ciências Biomédicas Abel Salazar, Universidade do Porto, Porto, Portugal; ' Serviço de Gastrenterologia, Hospital de Braga, Braga, Portugal; ' Instituto de Investigações em Ciência da Vida e Saúde, Escola de Medicina, Universidade do Minho, Braga, Portugal; e Serviço Gastroenterologia, Hospital Professor Doutor Fernando Fonseca, Amadora, Portugal; ${ }^{f}$ Serviço de Gastrenterologia, Hospital da Senhora da Oliveira, Guimarães, Portugal; 9 Serviço de Gastrenterologia, Hospital e Instituto CUF, Porto, Portugal; ' Serviço de Gastrenterologia, Hospital de São Teotónio, Viseu, Portugal; ' Serviço de Gastrenterologia, Centro Hospitalar e Universitário de Coimbra, Coimbra, Portugal; jServiço de Gastrenterologia, Hospital do Espírito Santo, Évora, Portugal; kServiço de Gastrenterologia, Centro Hospitalar de São João, Porto, Portugal; 'Serviço de Gastrenterologia, Hospital de Santa Maria, Centro Hospitalar

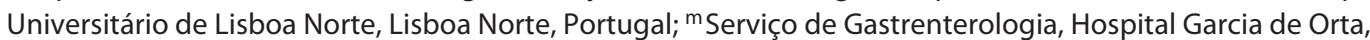
Almada, Portugal

Keywords

Hemorrhoidal disease $\cdot$ Consensus $\cdot$ Portugal

\section{Abstract}

Hemorrhoidal disease (HD) is a frequent health problem with considerable repercussions on patients' quality of life. However, much of the clinical practice related to HD is based on knowledge without scientific evidence and supported largely by empirical experience of the physician who deals with this pathology. As in other countries, the goal of this consensus is to establish statements supported by solid scientific evidence and whose purpose will be to standardize and guide the diagnosis and management of HD both in the general population and in some particular groups of patients.

C 2019 Sociedade Portuguesa de Gastrenterologia Published by S. Karger AG, Basel
Consenso da Sociedade Portuguesa de Gastrenterologia sobre o Diagnóstico e Tratamento da Doença Hemorroidária

Palavras Chave

Doença Hemorroidária · Consenso · Portugal

\section{Resumo}

A doença hemorroidária é uma patologia prevalente com repercussões consideráveis na qualidade de vida dos doentes. No entanto, muita da prática clínica relacionada com a doença hemorroidária é baseada em conhecimentos sem evidência científica e apoiada largamente por uma experiência empírica por parte do médico que lida com esta patologia. À semelhança do que tem sido feito noutros países, o objetivo deste consenso foi estabelecer

\section{KARGER}

E-Mail karger@karger.com www.karger.com/pjg
(C) 2019 Sociedade Portuguesa de Gastrenterologia Published by S. Karger AG, Basel

Karcer

Open access

This article is licensed under the Creative Commons AttributionNonCommercial-NoDerivatives 4.0 International License (CC BYNC-ND) (http://www.karger.com/Services/OpenAccessLicense) Usage and distribution for commercial purposes as well as any distribution of modified material requires written permission.
Paulo Sérgio Durão Salgueiro Serviço Gastroenterologia Centro Hospitalar e Universitário do Porto

Rua da Maternidade 56, PT-4050-369 Porto (Portugal)

E-Mail paulosalgueiro@gmail.com 
statements suportados por evidência científica sólida e cuja finalidade será o de uniformizar e orientar o diagnóstico e tratamento da doença hemorroidária quer na população em geral quer em grupos particulares de doentes.

๑ 2019 Sociedade Portuguesa de Gastrenterologia Publicado por S. Karger AG, Basel

\section{Introduction}

Hemorrhoidal disease (HD) is a prevalent condition among industrialized societies. It is one of the leading causes for a visit to a coloproctology's office. Given the large number of symptoms and associated patient distress, it is important that this disease is correctly diagnosed and treated.

Several guidelines and consensus have been published in recent years, addressing this issue $[1,2]$. Nevertheless, a national guideline has not been published to date. Therefore, this workgroup was developed to elaborate statements that should aid in clinical practice.

Given that a lot of information regarding this field is either outdated or without published evidence, an effort was made to select a group of participants considered as experts in HD.

Prior to this meeting, an invitation was sent to 12 prominent gastroenterologists with interest in proctology asking for the elaboration of statements addressing the different subthemes included in this document and, through research in scientific literature and/or clinical experience, the statements were revised and classified according to the quality of evidence [3] (online suppl. Appendix 1; for all online suppl. material, see www.karger. com/doi/10.1159/000502260).

On the consensus meeting, each statement was voted (anonymously, through an electronic application) with the options A (Agree) and B (Disagree). A minimum of 10 votes $(80 \%)$ on the option A was necessary to obtain consensus. If the statement did not reach 10 votes, it was either changed until a consensus was obtained or excluded.

The meeting was held in Curia, Portugal, on February 24, 2019 with the scientific support of SPG - Sociedade Portuguesa de Gastrenterologia.

A summary of the consensus is provided in online supplementary Appendix 2 and an algorithm for the management of patients with suspected HD in Figure 1.

\section{Physiopathology of $H D$}

The functional anal canal is approximately $4 \mathrm{~cm}$ in length (from the anal verge to distal rectum) [4-7]. The dentate line, approximately $2 \mathrm{~cm}$ above the anal verge, is a major anatomic point when considering the physiology and physiopathology of HD since, distal to the dentate line, the anal canal is lined with squamous epithelium covering the external hemorrhoidal plexus that is innervated by the somatic nervous system and highly sensitive to pain [4-7]. Internal hemorrhoids are located proximal to the dentate line, where the anal canal is lined with columnar epithelium as in the rectum. This tissue lacks sensitivity due to its innervation by the sympathetic and parasympathetic nervous systems, primarily distinguishing only fullness and pressure [4-7]. There are typically 3 major anal cushions above the dentate line (right anterior, right posterior, and left lateral) often with some minor accessory cushions between them [8].

The pathogenesis of HD is most likely multifactorial including deterioration of anchoring connective tissue of anal cushions, downward displacement or prolapse of the hemorrhoidal tissue [9], hyperperfusion state and neovascularization with abnormal distention of the arteriovenous anastomoses and veins of the internal hemorrhoidal venous plexuses [10], overexpression of inflammatory mediators [11], and increased resting anal pressure $[12,13]$.

Chronic constipation is usually considered to contribute to the occurrence of HD by causing an increased shearing force on the anal cushions and decreased venous return leading to degeneration of the supportive tissue in the anal canal and distal displacement of anal cushions [14-16]. Although this concept has been recently challenged [17], it remains one of the most consistently accepted risk factor for HD. Other conditions associated with increased intra-abdominal pressure, such as pregnancy [18], prolonged sitting, or heavy lifting are believed to cause $\mathrm{HD}$ as a result of compromised venous drainage of hemorrhoid plexus [19]. Advancing age, obesity, and sedentarism have also been reported to contribute to symptoms onset [4,20-23]. Chronic diarrhea is also a risk factor for developing HD due to frequent stool passage causing local trauma and weakening of the anal canal lining $[13,24]$. Data are inconsistent regarding the presumed correlation between HD and habits such as smoking, spicy foods, or alcohol consumption $[7,25]$. There is currently no consistent scientific evidence regarding any genetic predisposition to HD [26].

\section{Epidemiology}

HD is commonly diagnosed in clinical practice [26]. The reported prevalence in adults is highly variable, from $4.4 \%$ in self-reporting surveys [27] to $38.9 \%$ in screening 


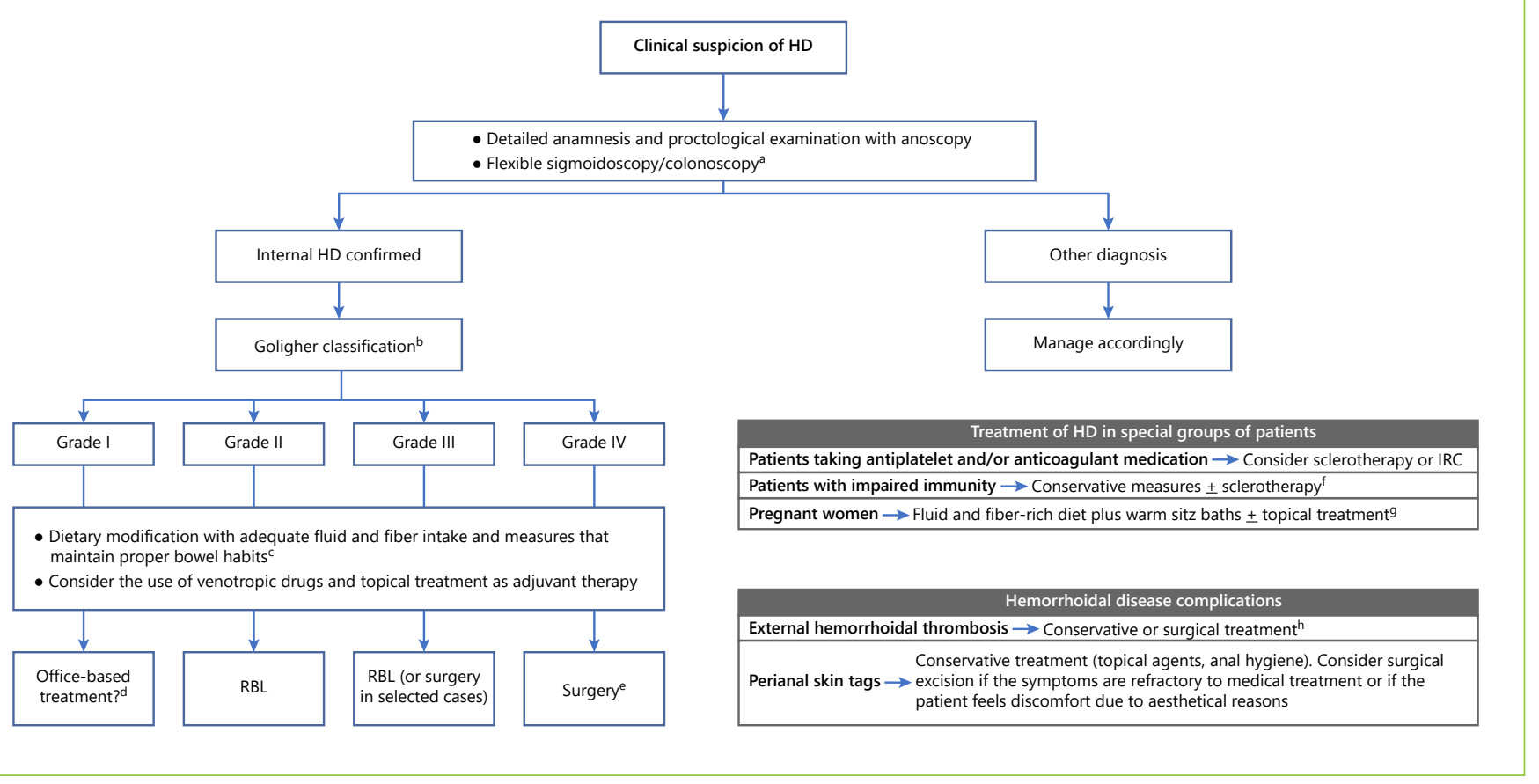

Fig. 1. Algorithm for the management of patients with suspected

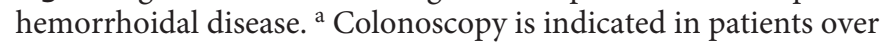
the age of 50 years (earlier if there is family history of CRC or another condition predisposing to CRC) or if any alarm symptom is present; ${ }^{b}$ consider using a symptom-based score, such as Sodergren score, to evaluate the severity of the $\mathrm{HD} ;{ }^{\mathrm{c}}$ advise avoiding excessive straining and limit the time at defecation; ${ }^{\mathrm{d}}$ medical management is enough for most patients. Some cases may require office-based treatment. RBL may be difficult to perform in such small vascular cushions; ${ }^{\mathrm{e}}$ the adopted type of surgical technique

colonoscopy setting [23]. HD affects both sexes equally, with a peak prevalence occurring between the ages of $45-$ 65 years, being unusual before the third decade [27].

\section{Clinical Evaluation and Diagnostic Tests}

\section{Statement 1}

A detailed history and proctological examination are mandatory in patients with suspicion of symptomatic HD (high-quality evidence).

Agreement: $100 \%$.

\section{Statement 2}

Anoscopy is the gold standard for the evaluation of the anus if $\mathrm{HD}$ is suspected (moderate-quality evidence).

Agreement: 100\%. will depend on local expertise and should be a joint decision between the doctor and the patient; ${ }^{\mathrm{f}}$ studies have suggested a potential benefit of antibiotic prophylaxis in these patients owing to the risk of bacteremia after sclerotherapy; ${ }^{g}$ there are no trials evaluating office-based therapies in pregnant women; therefore, they should probably be avoided during this period; ${ }^{\mathrm{h}}$ surgical treatment is effective in the prevention of recurrence and symptom control when applied during the first $48-72 \mathrm{~h}$ after symptoms onset. HD, hemorrhoidal disease; RBL, rubber band ligation; IRC, infrared coagulation.

\section{Statement 3}

Flexible sigmoidoscopy should be performed in patients with rectal bleeding. Colonoscopy is indicated in patients over the age of 50 years (earlier if there is family history of colorectal cancer [CRC] or another condition predisposing to CRC) or if any alarm symptom is present (moderate-quality evidence).

Agreement: 100\%.

\section{Rationale}

Internal HD is associated with painless bleeding (usually related to bowel movement), mucus discharge, soiling, and pruritus [5].

When patients complain of a significant anal pain, other diagnosis must be considered, such as anal fissure or inflammatory bowel disease (IBD) [5, 27]. 
Patient history must include information regarding the presence of alarm symptoms, whether constipation or diarrhea coexist and relationship between symptoms and defecation. Family history must also be included with a detailed cancer history to stratify CRC risk and history of IBD.

A proctological examination should be performed allowing the evaluation of the anal verge and its structures excluding a distal rectal mass or an anorectal abscess $[8$, 28]. Moreover, anoscopy seems to be the most accurate method to diagnose HD and can be performed in the office setting with no prior preparation $[28,29]$.

Patients over the age of 50 years or with alarm symptoms/signs (anemia, iron deficiency, abdominal pain, diarrhea, weight loss, or fever) or with risk factors for CRC/ IBD should undergo colonoscopy. It also should be highlighted that HD alone does not affect the prevalence of positive occult blood tests so, in case of a positive result, it should not be attributed to HD until a colonoscopy is performed [30-32].

Flexible sigmoidoscopy should be considered in patients who do not meet any of the criteria described above.

\section{HD Grading}

\section{Statement 4}

Although never validated, the most widely used score is the Goligher classification. Other classification systems were proposed, however, never gained widespread acceptance (low-quality evidence).

Agreement: 100\%.

\section{Statement 5}

A symptom-based score, such as Sodergren score, can be used to evaluate the severity of the HD (moderatequality evidence).

Agreement: 83\%.

\section{Rationale}

No unified tool exists to classify the severity of HD [2, 33]. The most widely used is the Goligher classification [34]. It categorizes only internal hemorrhoids and defines 4 grades of HD according to the most prolapsed pile. However, there is a frequent disparity between worsening symptoms and Goligher grade increment.

New classification systems for HD were proposed over the past 3 decades [35-38]. Some authors categorized HD in bleeding, prolapsing, thrombotic, and mixed HD [37]. This classification, based on histological evaluation of the anal canal in different stages of life, shed new light on the pathophysiology of HD. Other authors, using a retroflexed colonoscope, proposed a classification based on a detailed anatomical description [38]. Their algorithm included the degree of mucosal elevation of the rectal columns, changes in color, and the existence and size of hypertrophied anal papillae evaluated by colonoscopy. The Sodergren score [39] was developed and validated in 2015 using a simple symptom-based scoring system to quantify the severity of HD. In this study, 50 patients were scored with rectal bleeding according to the severity and frequency of pruritus, pain at rest, pain at defecation, and prolapse.

The single pile hemorrhoid classification (2015) is a new tool that considers the number of pathological piles, the characteristics of each internal pile (incorporating here the Goligher classification), and the characteristics of each external pile [33].

Although interesting from a descriptive point of view, these new classification systems are not widely used, perhaps because of their complexity. Probably no scoring system will ever be completely satisfactory.

\section{Medical Management of HD}

\section{Diet, Transit Modifiers, and Laxatives}

Statement 6

Dietary fiber (in food or as supplement) decrease bleeding and the recurrence of symptoms. The use of fiber is recommended in the treatment of acute episodes and to prevent recurrence (high-quality evidence).

Agreement: 92\%.

\section{Statement 7}

Patients with HD benefit from measures that maintain proper bowel habits such as avoiding straining and limiting the time at defecation (moderate-quality evidence).

Agreement: $100 \%$.

\section{Rationale}

As discussed above, HD has been considered to be caused by a low-fiber diet and constipation [40, 41]. Medical therapy involves dietary modification with adequate fluid and fiber intake, along with avoiding straining as well as diarrhea [42]. Data on fiber have been assessed in a systematic review and meta-analysis of 7 trials, which included 378 patients randomized in 2 groups: fiber group versus nonfiber group [43]. The results suggested that fiber has an apparent beneficial effect. Alongside with dietary supplementation, patients benefit from mea- 
sures that maintain proper bowel habits such as avoiding straining during passing motions, limiting the time at defecation, and once a day defecation [44]. There is lack of supporting evidence for the efficacy of other laxatives in the treatment of HD.

\section{Venotropic Drugs and Topical Treatment}

Statement 8

Venotropic drugs seem to be effective in the treatment of symptomatic HD. There is a lack of evidence about optimal dosage, duration of treatment, or superiority of a specific drug (moderate-quality evidence).

Agreement: 100\%.

\section{Statement 9}

Topical treatment may be useful in the short-term treatment of symptoms of HD but, so far, its use is not supported by well-designed, robust studies (moderatequality evidence).

Agreement: 92\%.

\section{Rationale}

The main goal of pharmacological treatment is to relieve acute symptoms of HD rather than reverting its chronic structural changes. Venotropics are a heterogeneous class of drugs used to treat chronic venous insufficiency [45] that have also been proposed for the treatment of HD [46]. Most of these drugs are derived from natural products extracted from plants, predominantly bioflavonoids. The precise mechanism of action has not been well established. There is some evidence in the literature that this class of drugs plays a role in the control of symptoms from HD [46]. A meta-analysis of 14 randomized controlled trials involving 1,514 patients and comparing various flavonoids formulations (diosmin + hesperidin micronized purified flavonoid fraction, diosmin, and rutosides) with placebo or no therapy reported an overall significant symptomatic improvement, namely, a beneficial effect on bleeding, pain, and itching. Moreover, the few studies evaluating symptom recurrence also showed a favorable effect [47]. A more recent Cochrane review expanded this evaluation to 24 trials involving 2,334 patients comparing venotropics (mostly flavonoids with some studies also evaluating calcium dobesilate) with a control intervention or no treatment and found relatively similar favorable results in overall improvement and in each symptomatic parameter [48]. No serious adverse events were reported with bioflavonoids besides mild gastrointestinal disturbances $[47,48]$; however, agranulocytosis has been described with calcium dobesilate [49].
Despite these encouraging results, both the Cochrane review and the meta-analysis emphasize the limitations in methodological quality and the heterogeneity of data among trials, leaving uncertainty about the real efficacy of venotropics in the treatment of symptomatic $\mathrm{HD}$ and advising that larger and better designed trials are necessary to achieve high-quality evidence.

Drugs available for topical application (mostly ointments or creams and suppositories) may contain analgesics/anesthetics (e.g., cinchocaine), steroids (e.g., hydrocortisone), venotropics (e.g., ruscogenin), spasmolytics (e.g., trimebutin), vasoconstrictors (e.g., phenylephrine), antiseptics, and emollients, either isolated or in association. The mechanism of action of some of these drugs has not been clarified. Evidence of efficacy has not been adequately demonstrated as most studies involve few patients and centers, have not been adequately designed or are outdated, and have not been replicated. Even though some studies involved significant number of patients, such as the review on policresulen plus cinchocaine reporting beneficial effect in 1,904 (83.2\%) out of 2,287 patients [50] or the review on several studies of tribenoside plus lidocaine [51], strong evidence cannot be drawn from the studies designed to provide a clear recommendation. Caution must be taken with prolonged or iterative use of topical medication because allergic reactions or sensitization may occur [52-54].

A few more recent and so far isolated reports of randomized clinical trials showed benefit from a gel containing hyaluronic acid with tea tree oil and methyl-sulfonylmethane in a single-center study with a small number of patients [55] and from an intra-anal ointment with iferanserin, a selective serotonin receptor antagonist, evaluated in a multicentric study [56].

A Cochrane review on traditional Chinese medicine herbs found no evidence to support its use in HD [57].

\section{Office-Based Treatment of HD}

\section{Rubber Band Ligation}

Statement 10

Rubber band ligation (RBL) is recommended as firstline treatment for internal grade II HD and for selected patients with grade III that do not respond to medical treatment. This technique is more effective and equally safe compared to sclerotherapy (liquid sclerosants) and infrared coagulation (IRC; high-quality evidence).

Agreement: 92\%.
Salgueiro et al. 
Statement 11

For internal grade II HD, RBL has similar efficacy but fewer side effects than excision hemorrhoidectomy (moderate-quality evidence).

Agreement: 100\%.

Rationale

Interventional management of $\mathrm{HD}$ can be divided in office-based or surgical procedures [58, 59].

The various nonsurgical treatments can be performed as outpatient procedures without anesthesia [59].

$\mathrm{RBL}$ involves placing rubber bands around hemorrhoids until they eventually fall off. It is a quick, simple, inexpensive procedure [59]. The elastic bands are applied on an insensitive area just above the dentate line to strangulate the piles leaving an area where inflammation fixes the mucosa to the submucosa preventing subsequent development of new hemorrhoidal tissue and is the most widely used nonsurgical treatment for patients with grade II or III HD [60]. Data regarding efficacy of RBL in grades I and IV are occasionally reported. The overall subjective improvement with RBL ranges from 73 to $84 \%$ [60]. A meta-analysis of 18 randomized trials comparing various treatment methods for grades I to III HD concluded that RBL was more effective than sclerotherapy and that patients who underwent ligation were less likely to need subsequent therapy [61]. Also, compared to excision hemorrhoidectomy, RBL has similar results but without the side effects of excision hemorrhoidectomy for the treatment of grade II HD [59]. Although RBL is more painful than other outpatient modalities, complication rates are similar [61]. Postoperative pain ranges from 8 to $80 \%$ in different randomized controlled trials (RCT) [60]. Postoperative bleeding ranges from 1.20 to $36 \%$ in the majority of RCT, but there is one trial that reported $50 \%[60,62-64]$. Other complications include vagal symptoms, chronic ulcers, priapism, difficulty in urination, hemorrhoidal thrombosis, and, although extremely uncommon, severe pelvic sepsis [58]. Recurrences of bleeding and prolapse at follow-up occur, respectively, in $10-18 \%$ and in $2.2 \%$ of patients; 1 RCT reported higher percentages (46 and $34 \%$, respectively) [60].

\section{Sclerotherapy}

Statement 12

Sclerotherapy with liquid sclerosants is safe but poorly effective and therefore should be used only for grade I internal HD (high-quality evidence). Since postprocedural bleeding is uncommon, it should be considered for pa- tients who have higher bleeding risk (moderate-quality evidence).

Agreement: 92\%.

\section{Statement 13}

The use of other sclerosing techniques, such as polidocanol foam and aluminum sulfate and tanic acid (ALTA), seems to be safe and effective even in patients under anticoagulation and/or antiplatelet therapy. The efficacy and safety compared to other office-based procedures are yet to be defined (low-quality evidence).

Agreement: 100\%.

\section{Rationale}

Internal HD can be fulgurated or sclerosed through injection [65]. As with RBL, sclerotherapy does not require anesthesia (local or intravenous). The procedure is performed through an anoscope, being the sclerosant injected into the hemorrhoidal cushions above the dentate line $[7,60]$.

Sclerotherapy (with liquid sclerosants) is considered safe but poorly effective and, therefore, used only for small hemorrhoids. Postprocedural bleeding is uncommon and so should be considered for patients who have an elevated bleeding risk, such as those receiving anticoagulants.

The interpretation of published studies comparing sclerotherapy with elastic banding and hemorrhoidectomy is not always easy. Sclerosants used vary, as does the dose, injection method, puncture site, and the type of needle used. On the other hand, subjective evaluation of prolapse reduction, intermittent blood loss, and recurrence of HD make the analysis difficult.

Among the various sclerosing agents described, 2 have stood out in recent years for their effectiveness and safety: ALTA and polidocanol foam. An RCT with ALTA reported resolution of bleeding in $69-88 \%$ of grade I HD [66], while 3 case series showed an improvement of bleeding in $100 \%$ of grades II and III HD [65, 67, 68]. More than $90 \%$ of prolapses resolution in grade II HD is reported in an RCT and 2 case series [66, 68, 69]. Good results are shown also for grade III, but data are reported only by case series. A prospective study showed an overall prolapse improvement in 100\% of patients [70], while Yano reported $52 \%$ of improvement of prolapse in III degree [71]. Miyamoto et al. [69] and Tokunaga [72] in their case series showed an improvement for grade IV, too.

In Portugal, liquid polidocanol 1 or $2 \%$ is commonly injected through the anoscope in low doses. However, 
polidocanol foam seems to be a better sclerosant than the liquid form $[73,74]$.

In a recently published Portuguese study, 2,000 patients were treated with polidocanol foam (without control group). The authors concluded that this therapy was very successful, with $98 \%$ of the patients reporting satisfaction regarding bleeding control and prolapse reduction. Complications were rare and usually minor [75].

Complications of sclerotherapy are uncommon, with the most frequent being minor discomfort, tenesmus, or bleeding with the injection. The major complications are most often iatrogenic, owing to misplaced injections into nonhemorrhoidal tissues or with systemic injections into the vasculature. Urinary retention, rectourethral fistulas, rectovaginal fistulas, rectal perforations, infections, necrotizing fasciitis, sepsis, and death are rare complications [76-78].

Other Techniques: IRC, Cryotherapy,

Eletrocoagulation, and Heater Probe

Statement 14

IRC is an effective procedure in the treatment of grades I and II HD. When compared to RBL, IRC shows less postoperative pain but higher probability of recurrence (high-quality evidence).

Agreement: $100 \%$.

\section{Statement 15}

Other office-based procedures have shown inconsistent results, namely, electrotherapy (moderate-quality evidence), cryotherapy, heater probe, and argon plasma coagulation (high-quality evidence). Their use is not supported by recent evidence.

Agreement: 92\%.

\section{Rationale}

In addition to the techniques described earlier, a variety of procedures can be used for HD: IRC, bipolar diathermy (BD), direct current electrotherapy (DCE), cryotherapy, and heater probe. For these therapeutic techniques, there are not enough controlled studies, particularly recent, and many authors consider that they should be regarded as obsolete [79].

IRC focuses infrared radiation from a tungsten-halogen lamp via a polymer probe tip, resulting in protein necrosis within the hemorrhoid. One RCT evaluated the efficacy of IRC, flavonoids, and combination therapy for 5 days: the percentages of improvement of IRC for different grades of HD were 78,51 , and $22 \%$ for grades I, II, and
III HD, respectively, and efficacy increased when the technique was associated with flavonoids; interestingly, the efficacy of IRC alone was similar to 5 days of flavonoids alone [80]. RCTs comparing IRC with RBL [81-84] showed that both were well-accepted and highly efficacious methods for the treatment of internal hemorrhoids; in general, RBL was more effective in controlling symptoms and needs fewer additional treatments but is associated with more pain than IRC.

$\mathrm{BD}$ is a studied treatment for grades I, II, and III HD. Success rates range from 88 to $100 \%$ in randomized trials but do not eliminate prolapsing tissue [31]. About $12 \%$ of patients experience pain, bleeding, fissure, or spasm of the internal sphincter [31]. Compared with IRC, BD has some practical advantages but results are similar [85]. Comparing $\mathrm{BD}$ with heater probe efficacy was the same, but pain was more common and the time to symptom relief was shorter with heater probe [86].

DCE has no advantage compared with standard medical therapy in an RCT [87] and a limited control of prolapse in higher grade HD [88]. In another RTC, although more painful than sclerotherapy, DCE is a safe and a highly satisfactory procedure for treating early HD [89]. However, DCE has not been widely accepted because of the lengthy treatment time and similar efficacy compared with BD [90-92], RBL [87], and sclerotherapy [88].

As for cryotherapy, the cryoprobe of liquid nitrogen is applied to the hemorrhoid for about 3 min to produce liquefaction of frozen tissue, over the ensuing 2-3 weeks. Despite initial enthusiasm, this procedure is now only rarely used because of prolonged pain, foul-smelling discharge, and a greater need for additional therapy than closed hemorrhoidectomy [31].

\section{Treatment of HD in Special Groups of Patients}

\section{Statement 16}

In patients taking antiplatelet and/or anticoagulant medication, the risk of bleeding is increased after RBL (low-quality evidence). In these patients, sclerotherapy appears to be safe (moderate-quality evidence).

Agreement: 100\%.

\section{Statement 17}

Instrumental interventions should be used with caution in patients with impaired immunity. Antibiotic prophylaxis might be beneficial after office-based procedures (low-quality evidence).

Agreement: 100\%.
Salgueiro et al. 
Statement 18

The first-line treatment of symptomatic HD during pregnancy should include a fluid and fiber-rich diet (moderate-quality evidence). Warm sitz baths are also helpful (high-quality evidence).

Agreement: $100 \%$.

\section{Statement 19}

In pregnant women, rutosides (high-quality evidence), combination of tribenoside and lidocaine (moderatequality evidence), and hydrocortisone creams (low-quality evidence) seem effective in reducing symptoms of $\mathrm{HD}$. Although preliminary data suggest no increased risk during pregnancy, these therapies should be avoided during the first trimester (low-quality evidence).

Agreement: 92\%.

\section{Rationale}

Antiplatelet and anticoagulant medication appear to increase the risk of bleeding after RBL with published reports of massive and life-threatening hemorrhage [9396]. In a large retrospective study of 805 patients undergoing RBL, higher bleeding rates were encountered in patients on warfarin (25\%) and acetylsalicylic acid (7.5\%) compared with patients not taking these medications (2.9\%) [64]. It is believed that the highest risk of bleeding occurs between 10 and 14 days after the procedure [62, $93,94]$. This has led many authors to recommend patients to stop their medication 7-10 days before banding, followed by a further $7-10$ days thereafter $[93,97]$. In a large retrospective observational study including 364 patients undergoing $\mathrm{RBL}$, withholding antiplatelet medication 7-10 days after the procedure appeared to equalize the risk of bleeding to that of patients not taking antithrombotic medications [97].

In a case-matched series of 37 patients receiving sclerotherapy for symptomatic HD while on antiplatelet and/or anticoagulant therapy, there was no difference in postprocedure bleeding rates [65].

In a prospective study, 120 patients with liver cirrhosis without coagulation disorders were randomized to receive RBL or sclerotherapy for the treatment of HD. Both therapies proved to be safe and effective [98]. In another prospective randomized trial of 26 patients with cirrhosis and $\mathrm{HD}$, resolution of symptoms and complications were similar between patients receiving RBL and stapled hemorrhoidopexy [99]. Even though studies seem to suggest that office-based therapy is beneficial in patients with liver cirrhosis, the authors have considered that there is not enough solid evidence to elaborate a statement on this matter.

Portuguese Consensus on the Diagnosis and Management of $\mathrm{HD}$
HD is present in up to $10 \%$ of patients infected with human immunodeficiency virus [100]. Older studies have reported impaired tissue healing and an increased risk of anorectal sepsis in immunocompromised patients [101]. Wound healing may be specially compromised in patients with low CD4 counts [102]. This had led to the general belief that interventions should be avoided or performed with careful consideration in immunocompromised patients. Other reports, however, have demonstrated that surgery for HD is safe in these patients [103]. At this moment, it seems wiser to use conservative measures (fluid and fiber-rich diet, laxatives, warm sitz baths) as the first-line treatment [104]. There is a paucity of data evaluating the safety and efficacy of instrumental techniques in immunocompromised patients with HD. Anecdotal reports have shown significant complications in human immunodeficiency virus patients following RBL [105]. However, sclerotherapy may be an attractive alternative in these patients [70]. Studies have suggested a potential benefit of antibiotic prophylaxis in these patients owing to the risk of bacteremia after sclerotherapy [106].

The prevalence of HD during pregnancy can reach $85 \%$ during the third trimester $[107,108]$. Treating constipation by increasing fluid and fiber intake and taking a warm sitz bath 3 times a day may be helpful in improving symptoms from $\mathrm{HD}$. In a prospective comparative study, relief of HD symptoms was achieved in all 284 patients in the warm sitz bath group but only in $179 / 211$ patients in the control group [109].

Two randomized controlled trials including over 150 pregnant women have shown that rutosides are effective in treating symptomatic HD $[110,111]$. The safety of rutosides was demonstrated in another randomized controlled trial including 69 pregnant women with venous insufficiency [112]. The combination of tribenoside and lidocaine suppositories has been studied in an old randomized parallel double-blind randomized trial versus lidocaine suppositories ( $n=21$ vs. 20 ) and hydrocortisone suppositories ( $n=13$ vs. 13) [113]. In both occasions, the combination of tribenoside and lidocaine appeared to be safe and to relieve HD symptoms. In an observational study, $82.5 \%$ of 33 pregnant women reported clinical improvement with oral tribenoside or a combination of tribenoside and lidocaine suppositories [114]. Again, no adverse events were reported. Finally, in a populationbased study, oral tribenoside was associated with a higher risk of congenital hydrocephalus in children. However, this finding was based on only 4 cases [115]. Topical hydrocortisone has shown modest effectiveness in controlling hemorrhoidal symptoms in a randomized controlled

GE Port J Gastroenterol 2020;27:90-102 
study against a modified toilet seat device [116]. No side effects were reported in the study. In a prospective observational study, topical hydrocortisone cream was effective in decreasing HD symptoms in 88 pregnant women [117]. Side effects were not reported in both studies. The safety of topical hydrocortisone has been evaluated in a prospective nonrandomized multicenter study comparing 204 treated pregnant women with 204 controls. No differences were found in birth weight or rates of prematurity [118]. In an open study of 50 pregnant women, a combination of diosmin and hesperidin proved effective in treating HD. Although lack of a control group precludes conclusions, significant adverse events were not noted [119].

We could not find any studies addressing the safety of any of the former drugs in lactating women.

There are no trials evaluating office instrumental therapies in pregnant or lactating women. As concerns regarding their safety during pregnancy or lactation exist, they should probably be avoided during this period.

Lastly, we should mention a specific group of patients, those with Crohn's disease. HD has been estimated in a 2012 study as affecting $1.6 \%$ of patients with Crohn's disease [120], but higher rates of prevalence (7\%) have been reported [121]. Surgery is usually not indicated in these patients, especially if the disease is not quiescent [122]. Conservative management is usually advised but nonetheless is often not effective in resolving HD. There is a paucity of studies involving the office-based treatment of HD in Crohn's disease [121], and as such, the authors have decided not to elaborate a statement on the matter.

\section{HD Complications}

\section{Statement 20}

The treatment of irreducible hemorrhoidal prolapse should be surgical (high-quality evidence). New sclerosing techniques may be a promising alternative (low-quality evidence).

Agreement: 100\%.

\section{Statement 21}

Treatment of external hemorrhoidal thrombosis can be conservative or surgical (high-quality evidence).

Agreement: 92\%.

\section{Rationale}

The treatment of irreducible hemorrhoidal prolapse (Goligher grade IV) is surgical [123]. Although excision- al hemorrhoidectomy is the most widely used technique in the world for irreducible hemorrhoidal prolapse, the comparison between surgical techniques for the treatment of grade IV HD does not show superiority of one method over another and is mainly a joint decision between the doctor and the patient $[123,124]$.

Although surgical treatment is quite effective in the treatment of external hemorrhoidal thrombosis, allowing the prevention of recurrence and symptom control, there is a clear lack of randomized prospective studies that allow to establish surgery as the gold standard in the treatment of this condition [125-127]. Surgical excision of external hemorrhoidal thrombosis relieves symptoms markedly on the fourth postoperative day when compared to conservative treatment [125]. One of the main doubts that remain is the optimal timing for surgery. Also, there is no evidence in the literature to support conservative treatment in the first $48-72 \mathrm{~h}$ of symptoms; however, clinical practice seems to favor this approach [126]. Thus, choosing between conservative treatment and surgery should take into account the patient's will and the clinician's experience [127].

There is a lack of studies aimed at the treatment of anal skin tags in patients with no other rectal pathology. Reference should be made to the existence of guidelines (which take the form of a systematic review) of the German Society of Coloproctology in conjunction with the German Society of Dermatology, but these guidelines are mostly based on studies over 30 years old [128]. In these guidelines, anal skin tags are considered to be mainly an esthetic problem, which only becomes more burdensome when it interferes with the hygiene of the patient. Thus, asymptomatic anal skin tags should not be treated, and careful hygiene should be carried out with water. The treatment of symptomatic anal skin tags should be made conservatively, with topical agents, anal hygiene, and regular habits of defecation. Fibrous skin tags that cause skin irritation or pressure on contralateral areas can be removed surgically.

\section{Final Thoughts}

$\mathrm{HD}$ is a common disorder that appears very often on the clinical setting. Nevertheless, from our experience, most of the knowledge and techniques that gastroenterologists use in the management of this disease are based in somewhat outdated literature or from peer learning, and no comprehensive approach to this matter is available for the Portuguese reality.
Salgueiro et al. 
Our goal was to elaborate statements based on the most recent literature paying attention to evidence level. This way, we aimed to reinforce correct patterns of knowledge and practice to meet the standards of published evidence also trying to highlight new information on the subject. Another end point we would like to achieve is the uniformization of clinical practice regarding this disease among gastroenterologists.
It should be noted, however, that some of the topics need further research and emphasis should be made on more studies regarding several of the office-based methods available, such as sclerotherapy.

\section{Disclosure Statement}

P. Salgueiro and P. Amaro received fees as speakers from Angelini Farmacêutica Lda.

\section{References}

1 Davis BR, Lee-Kong SA, Migaly J, Feingold DL, Steele SR. The American Society of Colon and Rectal Surgeons Clinical Practice Guidelines for the Management of Hemorrhoids. Dis Colon Rectum. 2018 Mar;61(3):284-92.

2 Trompetto M, Clerico G, Cocorullo GF, Giordano P, Marino F, Martellucci J, et al. Evaluation and management of hemorrhoids: italian society of colorectal surgery (SICCR) consensus statement. Tech Coloproctol. 2015 Oct; 19(10):567-75.

3 Atkins D, Best D, Briss PA, Eccles M, FalckYtter Y, Flottorp S, et al.; GRADE Working Group. Grading quality of evidence and strength of recommendations. BMJ. 2004 Jun; 328(7454): 1490.

4 Rakinic J, Poola VP. Hemorrhoids and fistulas: new solutions to old problems. Curr Probl Surg. 2014 Mar;51(3):98-137.

5 Sun Z, Migaly J. Review of Hemorrhoid Disease: presentation and Management. Clin Colon Rectal Surg. 2016 Mar;29(1):22-9.

6 Ganz RA. The evaluation and treatment of hemorrhoids: a guide for the gastroenterologist. Clin Gastroenterol Hepatol. 2013 Jun; 11(6):593-603

7 Jacobs D. Clinical practice. Hemorrhoids. N Engl J Med. 2014 Sep;371(10):944-51.

8 Sneider EB, Maykel JA. Diagnosis and management of symptomatic hemorrhoids. Surg Clin North Am. 2010 Feb;90(1):17-32.

9 Lohsiriwat V. Hemorrhoids: from basic pathophysiology to clinical management. World J Gastroenterol. 2012 May; 18(17): 2009-17.

10 Chung YC, Hou YC, Pan AC. Endoglin (CD105) expression in the development of haemorrhoids. Eur J Clin Invest. $2004 \mathrm{Feb}$; 34(2):107-12.

11 Serra R, Gallelli L, Grande R, Amato B, De Caridi G, Sammarco G, et al. Hemorrhoids and matrix metalloproteinases: A multicenter study on the predictive role of biomarkers. Surgery. 2016 Feb;159(2):487-94.

12 Aigner F, Gruber H, Conrad F, Eder J, Wedel $\mathrm{T}$, Zelger B, et al. Revised morphology and hemodynamics of the anorectal vascular plexus: impact on the course of hemorrhoidal disease. Int J Colorectal Dis. 2009 Jan;24(1):105-13.
13 Delcò F, Sonnenberg A. Associations between hemorrhoids and other diagnoses. Dis Colon Rectum. 1998 Dec;41(12):1534-41.

14 Riss S, Weiser FA, Schwameis K, Mittlböck M, Stift A. Haemorrhoids, constipation and faecal incontinence: is there any relationship? Colorectal Dis. 2011 Aug;13(8):e227-33.

15 Talley NJ, Lasch KL, Baum CL. A gap in our understanding: chronic constipation and its comorbid conditions. Clin Gastroenterol Hepatol. 2009 Jan;7(1):9-19.

16 Peery AF, Sandler RS, Galanko JA, Bresalier RS, Figueiredo JC, Ahnen DJ, et al. Risk Factors for Hemorrhoids on Screening Colonoscopy. PLoS One. 2015 Sep;10(9):e0139100.

17 Sandler RS, Peery AF. Rethinking What We Know About Hemorrhoids. Clin Gastroenterol Hepatol. 2019 Jan;17(1):8-15.

18 Poskus T, Buzinskienė D, Drasutiene G, Samalavicius NE, Barkus A, Barisauskiene A, et al. Haemorrhoids and anal fissures during pregnancy and after childbirth: a prospective cohort study. BJOG. 2014 Dec;121(13):166671.

19 Loder PB, Kamm MA, Nicholls RJ, Phillips RK. Haemorrhoids: pathology, pathophysiology and aetiology. Br J Surg. 1994 Jul;81(7): 946-54.

20 Foxx-Orenstein AE, Umar SB, Crowell MD. Common anorectal disorders. Gastroenterol Hepatol (N Y). 2014 May;10(5):294-301.

21 Parés D, Abcarian H. Management of Common Benign Anorectal Disease: What All Physicians Need to Know. Am J Med. 2018 Jul;131(7):745-51.

22 Pigot F, Siproudhis L, Allaert FA. Risk factors associated with hemorrhoidal symptoms in specialized consultation. Gastroenterol Clin Biol. 2005 Dec;29(12):1270-4.

23 Riss S, Weiser FA, Schwameis K, Riss T, Mittlböck M, Steiner G, et al. The prevalence of hemorrhoids in adults. Int J Colorectal Dis. 2012 Feb;27(2):215-20.

24 D’Ugo S, Stasi E, Gaspari AL, Sileri P. Hemorrhoids and anal fissures in inflammatory bowel disease. Minerva Gastroenterol Dietol. 2015 Dec;61(4):223-33.
25 Altomare DF, Rinaldi M, La Torre F, Scardigno D, Roveran A, Canuti S, et al. Red hot chili pepper and hemorrhoids: the explosion of a myth: results of a prospective, randomized, placebo-controlled, crossover trial. Dis Colon Rectum. 2006 Jul;49(7):1018-23.

26 Jacobs DO. Hemorrhoids: what are the options in 2018? Curr Opin Gastroenterol. 2018 Jan;34(1):46-9.

27 Johanson JF, Sonnenberg A. The prevalence of hemorrhoids and chronic constipation. An epidemiologic study. Gastroenterology. 1990 Feb;98(2):380-6.

28 Kelly SM, Sanowski RA, Foutch PG, Bellapravalu S, Haynes WC. A prospective comparison of anoscopy and fiberendoscopy in detecting anal lesions. J Clin Gastroenterol. 1986 Dec;8(6):658-60.

29 Alonso-Coello P, Castillejo MM. Office evaluation and treatment of hemorrhoids. J Fam Pract. 2003 May;52(5):366-74.

30 Korkis AM, McDougall CJ. Rectal bleeding in patients less than 50 years of age. Dig Dis Sci. $1995 \mathrm{Jul} ; 40(7): 1520-3$.

31 Madoff RD, Fleshman JW; Clinical Practice Committee, American Gastroenterological Association. American Gastroenterological Association technical review on the diagnosis and treatment of hemorrhoids. Gastroenterology. 2004 May;126(5):1463-73.

32 Nakama H, Kamijo N, Fujimori K, Horiuchi A, Abdul Fattah S, Zhang B. Immunochemical fecal occult blood test is not suitable for diagnosis of hemorrhoids. Am J Med. 1997 Jun;102(6):551-4.

33 Elbetti C, Giani I, Novelli E, Fucini C, Martellucci J. The single pile classification: a new tool for the classification of haemorrhoidal disease and the comparison of treatment results. Updates Surg. 2015 Dec;67(4):421-6.

34 JC G. Duthie H, Nixon H. Surgery of the anus, rectum and colon. London: Bailliere Tindal; 1984.

35 Fukuda A, Kajiyama T, Kishimoto H, Arakawa H, Someda H, Sakai M, et al. Colonoscopic classification of internal hemorrhoids: usefulness in endoscopic band ligation. J Gastroenterol Hepatol. 2005 Jan;20(1):46-50. 
36 Lunniss PJ, Mann CV. Classification of internal haemorrhoids: a discussion paper. Colorectal Dis. 2004 Jul;6(4):226-32.

37 Morgado PJ, Suárez JA, Gómez LG, Morgado PJ Jr. Histoclinical basis for a new classification of hemorrhoidal disease. Dis Colon Rectum. 1988 Jun;31(6):474-80.

38 Sadahiro S, Mukai M, Tokunaga N, Tajima T, Makuuchi H. A new method of evaluating hemorrhoids with the retroflexed fiberoptic colonoscope. Gastrointest Endosc. 1998 Sep; 48(3):272-5.

39 Pucher PH, Qurashi M, Howell AM, Faiz O, Ziprin P, Darzi A, et al. Development and validation of a symptom-based severity score for haemorrhoidal disease: the Sodergren score. Colorectal Dis. 2015 Jul;17(7):612-8.

40 Burkitt DP, Graham-Stewart CW. Haemorrhoids-postulated pathogenesis and proposed prevention. Postgrad Med J. 1975 Sep; 51(599):631-6.

41 Burkitt DP. Varicose veins, deep vein thrombosis, and haemorrhoids: epidemiology and suggested aetiology. BMJ. 1972 Jun;2(5813): 556-61.

42 Rivadeneira DE, Steele SR, Ternent C, Chalasani S, Buie WD, Rafferty JL; Standards Practice Task Force of The American Society of Colon and Rectal Surgeons. Practice parameters for the management of hemorrhoids (revised 2010). Dis Colon Rectum. 2011 Sep; 54(9):1059-64

43 Alonso-Coello P, Mills E, Heels-Ansdell D, López-Yarto M, Zhou Q, Johanson JF, et al. Fiber for the treatment of hemorrhoids complications: a systematic review and meta-analysis. Am J Gastroenterol. 2006 Jan;101(1): 181-8

44 Garg P, Singh P. Adequate dietary fiber supplement and TONE can help avoid surgery in most patients with advanced hemorrhoids. Minerva Gastroenterol Dietol. 2017 Jun 63(2):92-6.

45 Martinez-Zapata MJ, Cosp XB, Moreno RM, Vargas E, Capellà D. Phlebotonics for venous insufficiency. Cochrane Database Syst Rev. 2005(3).

46 Misra MC, Imlitemsu. Drug treatment of haemorrhoids. Drugs. 2005;65(11):1481-91.

47 Alonso-Coello P, Zhou Q, Martinez-Zapata MJ, Mills E, Heels-Ansdell D, Johanson JF, et al. Meta-analysis of flavonoids for the treatment of haemorrhoids. Br J Surg. 2006 Aug; 93(8):909-20.

48 Perera N, Liolitsa D, Iype S, Croxford A, Yas$\sin \mathrm{M}$, Lang $\mathrm{P}$, et al. Phlebotonics for haemorrhoids. Cochrane Database Syst Rev. 2012 Aug;(8):CD004322.

49 Ibáñez L, Ballarín E, Vidal X, Laporte JR. Agranulocytosis associated with calcium dobesilate clinical course and risk estimation with the case-control and the case-population approaches. Eur J Clin Pharmacol. 2000 Dec; 56(9-10):763-7.
50 Espinosa DJ. [Analytical review of multicenter studies with polycresulene for hemorrhoidal pathologies]. Acta Gastroenterol Latinoam. 2000;30(3):177-86

51 Lorenc Z, Gökçe Ö. Tribenoside and lidocaine in the local treatment of hemorrhoids: an overview of clinical evidence. Eur Rev Med Pharmacol Sci. 2016 Jun;20(12):2742-51.

52 González Mahave I, Lobera T, Blasco A, Del Pozo MD. Allergic contact dermatitis caused by cinchocaine. Contact Dermat. 2008 Jan; 58(1):55-8.

53 Lodi A, Ambonati M, Coassini A, Kouhdari Z, Palvarini M, Crosti C. Contact allergy to 'caines' caused by anti-hemorrhoidal ointments. Contact Dermat. 1999 Oct;41(4):221-

54 Ramirez P, Sendagorta E, Floristan U, Feltes RA, Vidaurrazaga C. Allergic contact dermatitis from antihemorrhoidal ointments: concomitant sensitization to both amide and ester local anesthetics. Dermatitis. 2010 MayJun;21(3):176-7.

55 Joksimovic N, Spasovski G, Joksimovic V, Andreevski V, Zuccari C, Omini CF. Efficacy and tolerability of hyaluronic acid, tea tree oil and methyl-sulfonyl-methane in a new gel medical device for treatment of haemorrhoids in a double-blind, placebo-controlled clinical trial. Updates Surg. 2012 Sep;64(3):195-201.

56 Herold A, Dietrich J, Aitchison R. Intra-anal Iferanserin $10 \mathrm{mg}$ BID for hemorrhoid disease: a prospective, randomized, doubleblind, placebo-controlled trial. Clin Ther. 2012 Feb;34(2):329-40.

57 Gan T, Liu YD, Wang Y, Yang J. Traditional Chinese Medicine herbs for stopping bleeding from haemorrhoids. Cochrane Database Syst Rev. 2010 Oct;(10):CD006791.

58 McCloud JM, Jameson JS, Scott AN. Lifethreatening sepsis following treatment for haemorrhoids: a systematic review. Colorectal Dis. 2006 Nov;8(9):748-55.

59 Shanmugam V, Thaha MA, Rabindranath KS, Campbell KL, Steele RJ, Loudon MA. Rubber band ligation versus excisional haemorrhoidectomy for haemorrhoids. Cochrane Database Syst Rev. 2005 Jul;(3):CD005034.

60 Cocorullo G, Tutino R, Falco N, Licari L, Orlando G, Fontana T, et al. The non-surgical management for hemorrhoidal disease. A systematic review. G Chir. 2017 Jan-Feb;38(1): 5-14

61 MacRae HM, McLeod RS. Comparison of hemorrhoidal treatment modalities. A metaanalysis. Dis Colon Rectum. 1995 Jul;38(7): 687-94.

62 Bat L, Melzer E, Koler M, Dreznick Z, Shemesh E. Complications of rubber band ligation of symptomatic internal hemorrhoids. Dis Colon Rectum. 1993 Mar;36(3):287-90.

63 Chew SS, Marshall L, Kalish L, Tham J, Grieve DA, Douglas PR, et al. Short-term and longterm results of combined sclerotherapy and rubber band ligation of hemorrhoids and mucosal prolapse. Dis Colon Rectum. 2003 Sep; 46(9):1232-7.
64 Iyer VS, Shrier I, Gordon PH. Long-term outcome of rubber band ligation for symptomatic primary and recurrent internal hemorrhoids. Dis Colon Rectum. 2004 Aug;47(8): 1364-70.

65 Yano T, Nogaki T, Asano M, Tanaka S, Kawakami K, Matsuda Y. Outcomes of casematched injection sclerotherapy with a new agent for hemorrhoids in patients treated with or without blood thinners. Surg Today. 2013 Aug;43(8):854-8.

66 Takano M, Iwadare J, Ohba H, Takamura $\mathrm{H}$, Masuda Y, Matsuo K, et al. Sclerosing therapy of internal hemorrhoids with a novel sclerosing agent. Comparison with ligation and excision. Int J Colorectal Dis. 2006 Jan;21(1):4451.

67 Porrett TR, Lunniss PJ. A prospective randomized trial of consultant-led injection sclerotherapy compared with nurse practitioner-led noninvasive interventions in the management of patients with first and second degree haemorrhoids. Colorectal Dis. 2001 Jul;3(4):227-31.

68 Tsunoda A, Nakagi M, Kano N, Mizutani M, Yamaguchi K. Serum aluminum levels in dialysis patients after sclerotherapy of internal hemorrhoids with aluminum potassium sulfate and tannic acid. Surg Today. 2014 Dec; 44(12):2314-7.

69 Miyamoto H, Asanoma M, Miyamoto H, Shimada M. ALTA injection sclerosing therapy:non-excisional treatment of internal hemorrhoids. Hepatogastroenterology. 2012 Jan-Feb;59(113):77-80.

70 Scaglia M, Delaini GG, Destefano I, Hultén L. Injection treatment of hemorrhoids in patients with acquired immunodeficiency syndrome. Dis Colon Rectum. 2001 Mar;44(3): 401-4.

71 Yano T, Asano M, Tanaka S, Oda N, Matsuda Y. Prospective study comparing the new sclerotherapy and hemorrhoidectomy in terms of therapeutic outcomes at 4 years after the treatment. Surg Today. 2014 Mar;44(3): 449-53.

72 Tokunaga Y. Clinical utility of sclerotherapy with a new agent for treatment of rectal prolapse in patients with risks. J Clin Gastroenterol. 2014 Apr;48(4):356-9.

73 Moser KH, Mosch C, Walgenbach M, Bussen DG, Kirsch J, Joos AK, et al. Efficacy and safety of sclerotherapy with polidocanol foam in comparison with fluid sclerosant in the treatment of first-grade haemorrhoidal disease: randomised, controlled, single-blind, multicentre trial. Int J Colorectal Dis. 2013 Oct; 28(10):1439-47.

74 Miyamoto $\mathrm{H}$, Hada $\mathrm{T}$, Ishiyama $\mathrm{G}$, Ono $\mathrm{Y}$, Watanabe $H$. Aluminum potassium sulfate and tannic acid sclerotherapy for Goligher Grades II and III hemorrhoids: results from a multicenter study. World J Hepatol. $2016 \mathrm{Jul}$; 8(20):844-9. 
75 Fernandes V, Fonseca J. Polidocanol foam injected at high doses with intravenous needle: the (almost) perfect treatment of symptomatic internal hemorrhoids. GE Port J Gastroenterol. 2019 May;26(3):169-75.

76 Kaman L, Aggarwal S, Kumar R, Behera A, Katariya RN. Necrotizing fascitis after injection sclerotherapy for hemorrhoids: report of a case. Dis Colon Rectum. 1999 Mar;42(3): 419-20.

77 Barwell J, Watkins RM, Lloyd-Davies E, Wilkins DC. Life-threatening retroperitoneal sepsis after hemorrhoid injection sclerotherapy: report of a case. Dis Colon Rectum. 1999 Mar;42(3):421-3

78 Schulte T, Fändrich F, Kahlke V. Life-threatening rectal necrosis after injection sclerotherapy for haemorrhoids. Int J Colorectal Dis. 2008 Jul;23(7):725-6.

79 Zindel J, Inglin R, Brügger L. [Necessary and unnecessary treatment options for hemorrhoids]. Ther Umsch. 2014 Dec;71(12):73751.

80 Dimitroulopoulos D, Tsamakidis K, Xinopoulos D, Karaitianos I, Fotopoulou A, Paraskevas E. Prospective, randomized, controlled, observer-blinded trial of combined infrared photocoagulation and micronized purified flavonoid fraction versus each alone for the treatment of hemorrhoidal disease. Clin Ther. 2005 Jun;27(6):746-54.

81 Gupta PJ. Infrared coagulation versus rubber band ligation in early stage hemorrhoids. Braz J Med Biol Res. 2003 Oct;36(10):1433-9.

82 Linares Santiago E, Gómez Parra M, Mendoza Olivares FJ, Pellicer Bautista FJ, Herrerías Gutiérrez JM. Effectiveness of hemorrhoidal treatment by rubber band ligation and infrared photocoagulation. Rev Esp Enferm Dig. 2001 Apr;93(4):238-47.

83 Marques CF, Nahas SC, Nahas CS, Sobrado CW Jr, Habr-Gama A, Kiss DR. Early results of the treatment of internal hemorrhoid disease by infrared coagulation and elastic banding: a prospective randomized cross-over trial. Tech Coloproctol. 2006 Dec;10(4):312-7.

84 Poen AC, Felt-Bersma RJ, Cuesta MA, Devillé W, Meuwissen SG. A randomized controlled trial of rubber band ligation versus infra-red coagulation in the treatment of internal haemorrhoids. Eur J Gastroenterol Hepatol. 2000 May;12(5):535-9.

85 Walker AJ, Leicester RJ, Nicholls RJ, Mann $\mathrm{CV}$. A prospective study of infrared coagulation, injection and rubber band ligation in the treatment of haemorrhoids. Int J Colorectal Dis. 1990 May;5(2):113-6.

86 Jensen DM, Jutabha R, Machicado GA, Jensen ME, Cheng S, Gornbein J, et al. Prospective randomized comparative study of bipolar electrocoagulation versus heater probe for treatment of chronically bleeding internal hemorrhoids. Gastrointest Endosc. 1997 Nov; 46(5):435-43.
87 Azizi R, Rabani-Karizi B, Taghipour MA. Comparison between Ultroid and rubber band ligation in treatment of internal hemorrhoids. Acta Med Iran. 2010 Nov-Dec;48(6): 389-93.

88 Varma JS, Chung SC, Li AK. Prospective randomised comparison of current coagulation and injection sclerotherapy for the outpatient treatment of haemorrhoids. Int J Colorectal Dis. 1991 Feb;6(1):42-5.

89 Khan N, Malik MA. Injection sclerotherapy versus electrocoagulation in the management outcome of early haemorrhoids. J Pak Med Assoc. 2006 Dec;56(12):579-82.

90 Hinton CP, Morris DL. A randomized trial comparing direct current therapy and bipolar diathermy in the outpatient treatment of third-degree hemorrhoids. Dis Colon Rectum. 1990 Nov;33(11):931-2.

91 Randall GM, Jensen DM, Machicado GA, Hirabayashi K, Jensen ME, You S, et al. Prospective randomized comparative study of bipolar versus direct current electrocoagulation for treatment of bleeding internal hemorrhoids. Gastrointest Endosc. 1994 Jul-Aug;40(4):403-10.

92 Yang P, Wang YJ, Li F, Sun JB. Hemorrhoid sclerotherapy with the complication of abdominal compartment syndrome: report of a case. Chin Med J (Engl). 2011 Jun;124(12): 1919-20.

93 Beattie GC, Rao MM, Campbell WJ. Secondary haemorrhage after rubber band ligation of haemorrhoids in patients taking clopidogrel-a cautionary note. Ulster Med J. 2004 Nov;73(2):139-41.

94 Odelowo OO, Mekasha G, Johnson MA. Massive life-threatening lower gastrointestinal hemorrhage following hemorrhoidal rubber band ligation. J Natl Med Assoc. 2002 Dec; 94(12):1089-92.

95 Parker R, Gul R, Bucknall V, et al. Double jeopardy: pyogenic liver abscess and massive secondary rectal haemorrhage after rubber band ligation of haemorrhoids. Colorectal Dis. 2011 Jul;13(7):e184.

96 Patel S, Shahzad G, Rizvon K, Subramani K, Viswanathan P, Mustacchia P. Rectal ulcers and massive bleeding after hemorrhoidal band ligation while on aspirin. World J Clin Cases. 2014 Apr;2(4):86-9.

97 Nelson RS, Ewing BM, Ternent C, Shashidharan M, Blatchford GJ, Thorson AG. Risk of late bleeding following hemorrhoidal banding in patients on antithrombotic prophylaxis. Am J Surg. 2008 Dec;196(6):994-9.

98 Awad AE, Soliman HH, Saif SA, Darwish AM, Mosaad S, Elfert AA. A prospective randomised comparative study of endoscopic band ligation versus injection sclerotherapy of bleeding internal haemorrhoids in patients with liver cirrhosis. Arab J Gastroenterol. 2012 Jun;13(2):77-81.

99 Zaher T, Ibrahim I, Ibrahim A. Endoscopic band ligation of internal haemorrhoids versus stapled haemorrhoidopexy in patients with portal hypertension. Arab J Gastroenterol. 2011 Mar;12(1):11-4.
100 Luma HN, Eloumou SA, Fualefeh-Morfaw EA, Malongue A, Temfack E, Lekpa FK, et al. Anorectal pathology amongst HIV infected patients attending the Douala General Hospital: a cross-sectional study. Int J STD AIDS. 2017 Mar;28(4):389-96.

101 Morandi E, Merlini D, Salvaggio A, Foschi D, Trabucchi E. Prospective study of healing time after hemorrhoidectomy: influence of HIV infection, acquired immunodeficiency syndrome, and anal wound infection. Dis Colon Rectum. 1999 Sep;42(9):1140-4.

102 Consten EC, Slors FJ, Noten HJ, Oosting H, Danner SA, van Lanschot JJ. Anorectal surgery in human immunodeficiency virus-infected patients. Clinical outcome in relation to immune status. Dis Colon Rectum. 1995 Nov;38(11):1169-75.

103 Hewitt WR, Sokol TP, Fleshner PR. Should HIV status alter indications for hemorrhoidectomy? Dis Colon Rectum. 1996 Jun; 39(6):615-8.

104 North JH Jr, Weber TK, Rodriguez-Bigas MA, Meropol NJ, Petrelli NJ. The management of infectious and noninfectious anorectal complications in patients with leukemia. J Am Coll Surg. 1996 Oct;183(4):3228.

105 Buchmann P, Seefeld U. Rubber band ligation for piles can be disastrous in HIV-positive patients. Int J Colorectal Dis. 1989;4(1): 57-8.

106 Adami B, Eckardt VF, Suermann RB, Karbach U, Ewe K. Bacteremia after proctoscopy and hemorrhoidal injection sclerotherapy. Dis Colon Rectum. 1981 Jul-Aug;24(5): 373-4.

107 Abramowitz L, Sobhani I, Benifla JL, Vuagnat A, Daraï E, Mignon M, et al. Anal fissure and thrombosed external hemorrhoids before and after delivery. Dis Colon Rectum. 2002 May;45(5):650-5.

108 Kukla L, Bouchalova M, Shkiriak-Nyzhnyk Z, Chyslovska N, Golding J, Goodfellow S, et al. Chronic morbidity in women, namely in pregnancy. (Comparative study between West, Central and East European centres). Lik Sprava. 2008 Jan-Feb;(1-2):43-60.

109 Shirah BH, Shirah HA, Fallata AH, Alobidy SN, Hawsawi MM. Hemorrhoids during pregnancy: Sitz bath vs. ano-rectal cream: A comparative prospective study of two conservative treatment protocols. Women Birth. 2018 Aug;31(4):e272-7.

110 Titapant V, Indrasukhsri B, Lekprasert V, Boonnuch W. Trihydroxyethylrutosides in the treatment of hemorrhoids of pregnancy: a double-blind placebo-controlled trial. J Med Assoc Thai. 2001 Oct;84(10):1395400.

111 Wijayanegara H, Mose JC, Achmad L, Sobarna R, Permadi W. A clinical trial of hydroxyethylrutosides in the treatment of haemorrhoids of pregnancy. J Int Med Res. 1992 Feb;20(1):54-60.
Portuguese Consensus on the Diagnosis and Management of HD
GE Port J Gastroenterol 2020;27:90-102 DOI: 10.1159/000502260 
112 Bergstein NA. Clinical study on the efficacy of O-( $\beta$-hydroxyethyl)rutoside (HR) in varicosis of pregnancy. J Int Med Res. 1975; 3(3):189-93.

113 Moggian G. Sperimentazione clinica controllata di un derivato glicofuranosidico anti-emorroidario, per uso locale. Minerva Med. 1973 Jan;64(5):215-8.

114 Delarue T. Traitement de la maladie hemorroidaire pendant la grossesse et le post partum par le glyרvenol. Arch Med Ouest. 1977;9:637-41.

115 Kubicsek T, Kazy Z, Czeizel AE. Teratogenic potential of tribenoside, a drug for the treatment of haemorrhoids and varicose veins-a population-based case-control study. Reprod Toxicol. 2011 May;31(4): 464-9.

116 Lim SS, Yu CW, Aw LD. Comparing topical hydrocortisone cream with Hai's Perianal Support in managing symptomatic hemorrhoids in pregnancy: a preliminary trial. J Obstet Gynaecol Res. 2015 Feb;41(2):23847.

117 Vohra S, Akoury H, Bernstein P, Einarson TR, Pairaudeau N, Taddio A, et al. The effectiveness of Proctofoam-HC for treatment of hemorrhoids in late pregnancy. J Obstet Gynaecol Can. 2009 Jul;31(7):654-9.
118 Ebrahimi N, Vohra S, Gedeon C, Akoury H, Bernstein P, Pairaudeau N, et al. The fetal safety of hydrocortisone-pramoxine (Proctofoam-HC) for the treatment of hemorrhoids in late pregnancy. J Obstet Gynaecol Can. 2011 Feb;33(2):153-8.

119 Buckshee K, Takkar D, Aggarwal N. Micronized flavonoid therapy in internal hemorrhoids of pregnancy. Int $\mathrm{J}$ Gynaecol Obstet. 1997 May;57(2):145-51.

120 Eglinton TW, Barclay ML, Gearry RB, Frizelle FA. The spectrum of perianal Crohn's disease in a population-based cohort. Dis Colon Rectum. 2012 Jul;55(7):773-7.

121 Mahmoud NN, Halwani Y, Montbrun S, Shah PM, Hedrick TL, Rashid F, et al. Current management of perianal Crohn's disease. Curr Probl Surg. 2017 May;54(5):26298.

122 D'Ugo S, Franceschilli L, Cadeddu F, Leccesi L, Blanco GV, Calabrese E, et al. Medical and surgical treatment of haemorrhoids and anal fissure in Crohn's disease: a critical appraisal. BMC Gastroenterol. 2013 Mar; 13(1):47.
123 Altomare DF, Giuratrabocchetta S. Conservative and surgical treatment of haemorrhoids. Nat Rev Gastroenterol Hepatol. 2013 Sep;10(9):513-21.

124 Simillis C, Thoukididou SN, Slesser AA, Rasheed S, Tan E, Tekkis PP. Systematic review and network meta-analysis comparing clinical outcomes and effectiveness of surgical treatments for haemorrhoids. Br J Surg. 2015 Dec;102(13):1603-18.

125 Gebbensleben O, Hilger Y, Rohde H. Do we at all need surgery to treat thrombosed external hemorrhoids? Results of a prospective cohort study. Clin Exp Gastroenterol. 2009;2:69-74.

126 Chan KK, Arthur JD. External haemorrhoidal thrombosis: evidence for current management. Tech Coloproctol. 2013 Feb; 17(1):21-5.

127 Wroński K, Frąckowiak L. Surgical treatment of thrombosed external hemorrhoids - Case report and review of literature. Pol Ann Med. 2013;20(1):35-8.

128 Bruhl W. Anal Skin Tags Interdisciplinary Guidelines of the German Society of Coloproctology and the German Society of Dermatology. J Dtsch Dermatol Ges. 2017; $4(10): 892-3$. 